\title{
BIOLOGICAL CHEMISTRY
}

Founded in 1877 by Felix Hoppe-Seyler as Zeitschrift für Physiologische Chemie

Felix Hoppe-Seyler (1825-1895) was a pioneer of biochemistry, remembered not only for his discovery of hemoglobin and his contributions to the chemical characterization of many other biological compounds and processes but also for having been the mentor of Friedrich Miescher and Albrecht Kossel. In his preface to the first issue of Zeitschrift für Physiologische Chemie, Felix Hoppe-Seyler coined the term Biochemistry ('Biochemie') for the then newly emerging discipline.

\section{GBM}

Biological Chemistry is associated with the Gesellschaft für Biochemie und Molekularbiologie e.V. (GBM)
EDITOR-IN-CHIEF

D. Thomas, Chicago

EXECUTIVE EDITORS

B. Brüne, Frankfurt/Main

J. Buchner, Munich

J. Herrmann, Kaiserslautern

M. Lei, Shanghai

S. Ludwig, Münster

B. Turk, Ljubljana

A. Wittinghofer, Dortmund

EDITORIAL BOARD

P. Agostinis, Leuven

L. Banks, Trieste

A.G. Beck-Sickinger, Leipzig

L. Boscá, Madrid

E. Cadenas, Los Angeles

I. Dikic, Frankfurt/Main

W.-X. Ding, Kansas City

C. Hammann, Bremen

F.U. Hartl, Martinsried

D. Häussinger, Düsseldorf

J. Hiscott, Rome

L.-O. Klotz, Jena

V. Magdolen, Munich

G. Mugesh, Bangalore

M. Müschen, San Francisco

G. Pejler, Uppsala

N. Pfanner, Freiburg

J. Potempa, Krakow

K. Sandhoff, Bonn

J. Scheller, Düsseldorf

$H$. Sies, Düsseldorf

G. Tiegs, Hamburg

J.M. Valpuesta, Madrid

ASSOCIATE EDITORS (GBM STUDY GROUPS)

J.W. Bartsch, Marburg

S. Clemens, Bayreuth

A. Ebert, Göttingen

R. Erdmann, Bochum

K. Giehl, Giessen

S. Hiller, Basel

C. Hunte, Freiburg

I. Koch, Frankfurt/Main

T. Proikas-Cezanne, Tübingen

L. Randau, Marburg

J. Riemer, Cologne

C. Seidel, Düsseldorf

R. Sterner, Regensburg

C. Villmann, Würzburg

\section{DE GRUYTER}


ABSTRACTED/INDEXED IN Academic OneFile (Gale/Cengage Learning), ASFA1: Biological Sciences \& Living Resources, Biochemistry \& Biophysics Citation Index, Biological Abstracts, BIOSIS Previews, CAB Abstracts, Calcium and Calcified Tissue Abstracts, Chemical Abstracts and the CAS databases, CSA Illustrata - Natural Sciences, CSA Neurosciences Abstracts, Current Contents/Life Sciences, Elsevier BIOBASE/Current Awareness in Biological Sciences (CABS), EMBASE - the Excerpta Medica database, EMBiology, Index Medicus/MEDLINE, Journal Citation Reports/Science Edition, Reaction Citation Index, Reference Update, Science Citation Index, Science Citation Index Expanded (SciSearch), Scopus, SIIC Data Bases, Zoological Record.

The Journal is associated with the Gesellschaft für Biochemie und Molekularbiologie e.V. GBM

The publisher, together with the authors and editors, has taken great pains to ensure that all information presented in this work (programs, applications, amounts, dosages, etc.) reflects the standard of knowledge at the time of publication. Despite careful manuscript preparation and proof correction, errors can nevertheless occur. Authors, editors and publisher disclaim all responsibility for any errors or omissions or liability for the results obtained from use of the information, or parts thereof, contained in this work.

The citation of registered names, trade names, trademarks, etc. in this work does not imply, even in the absence of a specific statement, that such names are exempt from laws and regulations protecting trademarks etc. and therefore free for general use.

ISSN 1431-6730 · e-ISSN 1437-4315 · CODEN BICHF3

All information regarding notes for contributors, subscriptions, Open access, back volumes and orders is available online at www.degruyter.com/bc.

RESPONSIBLE EDITOR(S) Douglas D. Thomas, Department of Medicinal Chemistry and Pharmacognosy, University of Illinois at Chicago, College of Pharmacy, 900 S. Ashland Avenue (M/C 870), Chicago, IL 60607, USA, e-mail: ddthomas@uic.edu.

JOURNAL COORDINATOR Dr. Torsten Krüger, De Gruyter, Genthiner Straße 13, 10785 Berlin, Germany, Tel.: +49 (0)30 260 05-176, Fax: +49 (0)30 260 05-352, Email: biol.chem.editorial@ degruyter.com

RESPONSIBLE FOR ADVERTISEMENTS Markus Kügel, De Gruyter, Rosenheimer Str. 143, 81671 München, Germany. Tel.: +49 $8976902-424$, e-mail: anzeigen@degruyter.com

(C) 2021 Walter de Gruyter GmbH, Berlin/Boston

TYPESETTING TNQ Technologies, Chennai, India

PRINTING Franz X. Stückle Druck und Verlag e.K., Ettenheim

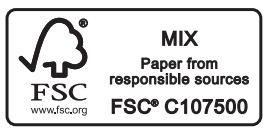




\section{Contents}

\section{Review}

Solomon Tsegaye, Gobena Dedefo and Mohammed Mehdi Biophysical applications in structural and molecular biology — 1155

\section{Research Articles/Short Communications}

\section{Genes and Nucleic Acids}

Andreas Thess, Ingmar Hoerr, Benyamin Yazdan Panah, Günther Jung and Ralf Dahm

Historic nucleic acids isolated by Friedrich Miescher contain RNA besides DNA 1179

\section{Protein Structure and Function}

Andreas Eichinger, Irmgard Neumaier and Arne Skerra The extracellular region of bovine milk butyrophilin exhibits closer structural similarity to human myelin oligodendrocyte glycoprotein than to immunological BTN family receptors — 1187

Rajendra P. Koirala, Rudramani Pokhrel, Prabin Baral, Purushottam B. Tiwari, Prem P. Chapagain and Narayan P. Adhikari

Structural insights into the repair mechanism of AGT for methyl-induced DNA damage — 1203

\section{Cell Biology and Signaling}

Minh Thi Hong Nguyen, Chien Van Tran, Phuong Hong Nguyen, Quang De Tran, Min-Sung Kim, Won-Kyo Jung and Phuong Thi Mai Nguyen In vitro osteogenic activities of sulfated derivative of polysaccharide extracted from Tamarindus indica L. 1213
Barbara Canonico, Luca Giorgi, Maria Gemma Nasoni, Mariele Montanari, Gianluca Ambrosi, Mauro Formica, Caterina Ciacci, Patrizia Ambrogini, Stefano Papa, Vieri Fusi and Francesca Luchetti Synthesis and biological characterization of a new fluorescent probe for vesicular trafficking based on polyazamacrocycle derivative 1225

Marius Stopp, Philipp A. Steinmetz and Gottfried Unden Properties of transmembrane helix TM1 of the DcuS sensor kinase of Escherichia coli, the stator for TM2 piston signaling — 1239

Ning Cui, Qiang Han, Qizhen Cao, Kejun Wang, Xujia Zhou, Pingzhi Hou, Chao Liu, Lungang Chen and Lin Xu

Lefty $A$ is involved in sunitinib resistance of renal cell carcinoma cells via regulation of IL-8 1247

\section{Proteolysis}

Marion Lavergne, Audrey Guillon-Munos, Woodys Lenga Ma Bonda, Sylvie Attucci, Thomas Kryza, Aurélia Barascu, Thierry Moreau, Agnès Petit-Courty, Damien Sizaret, Yves Courty, Sophie lochmann and Pascale Reverdiau

Tissue factor pathway inhibitor 2 is a potent kallikrein-related protease 12 inhibitor 1257 